\title{
The Competence of the Administrative Court and Administrative Justice
}

\author{
Aju Putrijanti \\ Faculty of Law, Universitas Diponegoro, Indonesia, E-mail:aputriyanti@yahoo.com
}

\begin{tabular}{|c|c|}
\hline Article Info & Abstract \\
\hline $\begin{array}{l}\text { Keywords: } \\
\text { Administrative Court, } \\
\text { Administrative Justice, Government } \\
\text { How to cite: } \\
\text { Aju Putrijanti, "The Competence of } \\
\text { Administrative Court and } \\
\text { Administrative Justice," Fiat } \\
\text { Justisia: Jurnal Ilmu Hukum 14, } 2 \\
\text { (2020):97-112. } \\
\text { DOI: } \\
\text { 10.25041/fiatjustisia.v14no2.1890 }\end{array}$ & $\begin{array}{l}\text { Administrative Court is a specialized court under the } \\
\text { Supreme Court with a role to settle the } \\
\text { administrative disputes included staffing disputes. } \\
\text { The legitimation of Law No. } 30 \text { of } 2104 \text { concerning } \\
\text { Government Administration has brought a new } \\
\text { paradigm in the governance framework. Also, the } \\
\text { competence of the Court is broader than before. In } \\
\text { Addition, some regulations give more competence to } \\
\text { the Court. It is normative juridical research. It uses } \\
\text { statute, conceptual approach to observed, analyzed } \\
\text { and discussion on the issues. This research is to } \\
\text { develop the relations between the competence of the } \\
\text { Court and administrative justice. Based on the } \\
\text { research, broader competence gives more } \\
\text { opportunity to get access to justice.In conclusion, } \\
\text { administrative justice has some meanings; first, it is } \\
\text { the rights of an individual. Therefore, the } \\
\text { government has to provide detail, clear information } \\
\text { for any individual before issuing a decree based on } \\
\text { the application, rights to claims and revision for any } \\
\text { mistakes. Second, the defendant must obey and } \\
\text { implement the judicial verdict. This obligation as an } \\
\text { implementation of administrative justice and legal } \\
\text { certainty for Plaintiff and obedience by the } \\
\text { Defendant to the judge verdict. Third, administrative } \\
\text { justice should be supported by the regulations by } \\
\text { obeying the judge verdict. This is part of improving } \\
\text { the quality of governance. }\end{array}$ \\
\hline
\end{tabular}

\section{A. Introduction}

Indonesia is a state of law, based on Pancasila as nation philosophy and the Constitution. The government consists of executive, legislative and judicative, which has separate and different authority. Judiciary system in Indonesia consists of Supreme Court and Constitution Court, with 4 (four) courts under the Supreme Court consisting of the general court, religion court, military court and administrative court. The aim of the courts is to law enforcement 
based on justice and Pancasila.The aim of Administrative Court (hereinafter as the Court), stated by S.F. Marbun, philosophically is to protect the individual and society rights, it can reach the congeniality, balance between both rights. Sjachran Basah said the aim is to harmonize and keep the balance condition for individually and government. The Court was formed for law enforcement and justice for the society against the government's acts in public law and caused by maladministration, violation of administrative law. ${ }^{1}$ This is a consequence in state law, and the participation of government's in the society. It should be a guardian to keep the consistency and harmonization of rights and obligations between society and government.

The Law No. 7 of 2017 concerning General Election gives more competence to the Court, this also has implications, but since there is no conflict of the norm with other courts, then so far there is no important discussion. There are some articles already discuss after Law No. 30 of 2014 concerning Government Administration has been legalized, and gives enlightenment for the public to realize the development. Some discussion about the competence of the Court to examine the abuse of authority already done, and based on principle lex posteriori derogat legi priori, the competence to examine and decide the abuse of authority is Administrative Court. ${ }^{2}$ There is no conflict of norm between the Court and Corruption Court because each has different competence to verify. Furthermore, there will no interfere for both Court. The differences opinion of the competence must be interesting, but it is also important to discuss, especially relates to justice and competence of the Court.

This aim of this article is to answer the questions of how is the development of competence of the Court and its influence on administrative justice, which makes this article interesting. The administrative justice is rare to discuss although it is a right beside other human rights, and also stated in Article No. 27 of Indonesia Constitution. The development competence of the Court shows that it gives benefit to society since they can get the administration justice as civil rights. ${ }^{3}$

Theory of Gustav Radburch to analyze the relations between the broader competence of the Court and the justice, and theory of Aristoteles to analyze the relations of administrative justice as an embodiment of distributive justice. The legal issue in this article is the competence of the Court based on the existing regulations, cannot fulfil the administrative justice as civil rights. The

\footnotetext{
${ }^{1}$ Enrico Simanjuntak, "Peradilan Tata Usaha Negara Dan Perlindungan Hak Asasi Manusia," in Perdebatan Hukum Administrasi Sebuah Kompilasi Artikel Hukum Administrasi, ed. Paskalina Oktavianawati (Bekasi: Gramata Publishing, 2018), 3-29.

${ }^{2}$ Mohammad Sahlan, "Kewenangan Peradilan Tipikor Pasca Berlakunya Undang-Undang No.30 Tahun 2014 Tentang Administrasi Pemerintahan," Arena Hukum 9, No. 2 (2016): 16689, https://doi.org/10.21776/ub.arenahukum.2016.00902.2.

${ }^{3}$ Lara M Pair, "Judicial Activism in the ICJ Charter Interpretation," Journal of International and Comparative Law 8, (2001): 181-221.
} 
broader competence of the Court relates to civil rights to get administrative justice in the state of law.

The broad competence of the Court and its implications has been discussed many times and have different conclusions. Some researchers said it needs harmonization and synchronization with other regulations or it does not need to argue between the competence of the Court and another court, or it should be followed by changes or makes new regulations to support the competence of the Court. Otherwise, it will make the lack of law enforcement. This article discusses the competence of the Court to get administrative justice, in the frame to protect civil rights. There has been a study about administrative justice is rare, especially relates to the Court.

The problems are how is the competence of the Court and how it relates to administrative justice? There has been tension between justice, legal certainty and law enforcement, and on the other side, there should be an opportunity to get access to justice for everyone. By this research, the administrative justice can be understood in some meanings, due to the Court and relates regulations. Moreover, it is related to the principle of good governance to give administrative justice for everyone. The novelty of this research is to find out the relations between the competence of the Court and to fulfil the administrative justice for the citizen.

This is normative juridical research and based on secondary data. The used secondary data are regulations, judge verdicts which had been legally binding as primary legal material. The secondary legal material which gives an explanation that will support the primary legal material, such as research result, conference or other relates documents. All the primary and secondary legal material will be classified, observed, and analyzed to find out the result of the research questions, also supported by interviewed with Judges. It uses the statute approach, conceptual approach and history approach to analyzed the research questions.

\section{B. Discussion}

\section{The competence of the Court}

\section{a. The Regulations}

The Dutch colonialization had influenced Indonesian law system so that Indonesian act also in accordance with the Civil Law system. East Asia countries, like Japan and China, had sought the German administrative law, in the late of nineteenth and twentieth centuries, also influenced by French 
administrative law in Turkey, and appropriate with their system of law ${ }^{4}$ The French Administrative Court, Counseil d'Etat, affected the formation of Indonesian Administrative Court, but there are still some divergences. It is also used as a role model of the Administrative Court in some countries.

Indonesia state of the law is a form of state chosen by the founding father and legalized in Article 1 para three the 1945 Constitution. The Indonesian state of the law has specific qualification based on Pancasila, which gives transparency to the legal and judiciary system in Indonesia and gives the possibility to adopt conception, legal system from other legal tradition in the world. ${ }^{5}$ In the beginning, Indonesian system law followed the Civil Law system as an impact from Dutch colonialized. In the globalization, modernization, it might become a mixed system of law, between common and civil law. The existence of the Court refers to the Indonesian state of law, as guardian to the administrative law, especially the rights and obligations of society and government. The case law of administrative law, become important as part of administrative law enforcement, besides regulations.

First, the regulations of the Court as general rules of conduct to proceed in the Court and structure of law, referring to the Theory of Law by Friedman, had been amended twice. The court aims to implement the welfare of nations, equality before the law, human rights protection for the citizen, which it should be based on Pancasila to reach the balance, in harmony and compatible. As stated by Oemar Seno Adji, as a characteristic of Indonesian Administrative Court, and completed by Paulus Effendi Lotulung, the Court has to supervise the government. In comparison with the judicial system in the Netherlands, they have developed interaction between the rule of law and New Public Management, which remodelled the judicial organization more streamlined and hierarchical system, and reform of judicial self-government affects the new reflections on the separation of powers by putting more guarantee on the functional independence of judges in the system. ${ }^{6}$ This relates to the independence of the judiciary, should be no interference by anyone, so transparency and openness are important.The judiciary system gives more attention to the independence and integrity of judges and guarantees to decide the cases freely. The innovation to develop new judiciary system based on values, new management, and the demands of society has to be made based on the research and in-depth study.

\footnotetext{
${ }^{4}$ J Anina B Boughey, "Administrative Law: The next Frontier for Comparative Law J," International and Law Quarterly 62, No. January (2013): 55-95, https://doi.org/10.1017/S0020589312000553.

${ }^{5}$ Imam Subechi, "Mewujudkan Negara Hukum Indonesia," Jurnal Hukum Dan Peradilan 1, No. 3 (2012): 339-58, https://doi.org/10.25216/jhp.1.3.2012.339-358.

${ }^{6}$ Elaine Mak, "Judicial Self Government in the Netherlands: Demarcating Autonomy," German Law Journal 19, No. 7 (2018): 1801-38.
} 
Second, the development of politic caused the amendment of Constitution, also gave impact to the judiciary system and has been changed since the amendment of Article No. 24 of Judicial Power, especially The Law No. 9 of 2004 concerning the Amendment of Law No 5 of 1986 concerning Administrative Court. There are some changes in the Law No 9 of 2004, for example, the requirements to become a judge for the Court, the supervision for the judge, the abolition for the third party, vide article No. 118, the reason for the lawsuit, the enforcement of judge verdict, the assignment and termination of the judge. The changes will be discussed in this article only related to the procedural in the Court. Previously in Article No. 53 para 2 of Law No. 5 of 1986 concerning Administrative Court put the abuse of power as the reason, besides against the law. While in Law No. 9 of 2004, the reason is against the law and principles of good governance.

The other changes in the enforcement of the judicial verdict, which becomes problems from the beginning the Court established. There are substantial changes in the article no. 116, it was written if the Defendant did not enforce the judge verdict, the Court will put in the newspaper as an announcement for the citizen that Defendant did not execute the judicial verdict. Also, there are fine and administrative sanction, will be given by the judge. The difficulties in obeying and enforce the judge verdict showed the lack of legal obedience of the government officer and/or body.

Third, the Law No. 51 of 2009 concerning Second Amendment of Law No 5 of 1986 concerning Administrative Court was made after there was changed in The Law No. 48 of 2019 concerning Judiciary Power. There were several changes, i.e. the recruitment and supervision of a judge, tax court as a specialized court under the Administrative Court, the ad-hoc judge, transparency of judiciary, the honorary assembly and the obligation of a judge to obey the code of ethic of Judge, legal assistance, the enforcement of judge verdict. Some important substances had been add to article No. 116, the Court will make a report to the Representative Body and President if the defendant did not enforce and obey the judge verdict, the rest of the article are the same with the previous one.

The transparency of judiciary system is important because it has 3 (three) important points, first is to protect the human rights, second as the implementation of the principle of good governance, third is to implement the principles of independence of the judiciary. Refer to Law No. 14 of 2008 concerning Public Information Disclosure. The Judicial system put the new system which everyone can get access to the Court by the internet, namely Case Tracking Information System (Sistem Informasi Penelusuran Perkara or SIPP) in every Court. Actually, this is a new progress of openness of the judiciary system in Indonesia.

To guarantee and protect the human rights, and the principle of equality before the law, in Article 144 C, 144 D of Law No. 51 of 2009 concerning 
Second Amendment, there is a legal aid in every Court and free for everyone. This is the implementation one of the principle of human rights, i.e. everyone has rights for equality before the law, so everyone entitled to have legal aid.

In Ukraine, the Administrative Court was created in 2004 as cassation instance as, then in 2005 regulates the jurisdiction of the administrative court, principle of handling the administrative case, principles of court administrative proceeding. The substantive competence of the Administrative Court is protection rights of legal interests of legal entities and collective entities against the government's decree, settlement the legal and administrative cases. The administrative court in Ukraine is established while there was the difficult condition with the opponents, the administrative court was formed as special courts of general jurisdiction, and today they are reforming their functions and administrative judicature to comply with the European Union. ${ }^{7}$ After the new regulations changed and legalized, then Administrative Court in Ukraine needs improvement from the existing regulations, system and organizations.

The changes and development of politics, the economy also gives impact to the judiciary system, governance and society. The Law No. 30 of 2014 concerning Government Administration is the first regulation of government administration, including the principles of good governance, the authority, the procedure to make and cancellation of the decree, the administrative sanction, the prohibition abuse of power, type of decree and other government act related to governing the society. The legalized of this regulation was belated than the regulation of the Court in 1986, even though this is important for the government.

As the first regulation of government administration, has brought the new paradigm in public service of administration governance to grow the public openness of information, furthermore to emphasize the responsibility of governance and as an important pillar of bureaucratic reform and implementation of principles of good governance. ${ }^{8}$ This new paradigm is important to increase and change the culture of the quality of public service by the government, while society as a subject of governance. Government officer/bodies and society should be well informed about these new regulations since there is still vagueness about the substances. The quality of public service must be better than before, and it relates to the culture of governments office when they give services.

There are some important substances in Law No. 30 of 2014, which gives impact to the competence of the Court. Article 20 and 21 of Law No. 30 of

\footnotetext{
${ }^{7}$ Tatiana Bilkiewicz et al., "Administrative Courts in Ukraine : Formation and Functioning in the Modern Conditions," Annuals of The Administration and Law 17, No. 1 (2017): 115-27. ${ }^{8}$ I Gusti Ngurah Wairocana et al., "The Expansion of Administrative Decision Meaning Based on Government Administration Law : A Dispute Submission Process Approach," 2019, 13-33, https://doi.org/10.24843/JMHU.2019.v08.i01.p02.
} 
2014 concerning Government Administration gives more competence to the Court. It can investigate the request valuation of abuse of power by the government. This was a problem when the act legalized, but on the other side, the regulations to implement is not ready yet. In-Law No. 5 of 1986 concerning Administrative Court and its amendments, there are no regulations of investigating the valuation of abuse of power, how is the standard of the procedure, the parties and the judge verdict, the possibility to appeal. This legal gap finalized by The Supreme Court issued the Regulation of Supreme Court No. 4 of 2015 concerning Arbitrary Valuation, to supervise and guidance for the Court to implement Article No. 20 and 21 Law No. 30 of 2014 concerning Government Administration.

The competence to make a valuation of abuse of power arise different opinions about competence between the Court and Corruption Court. Disiplin Manao explained that the legal settlement abuse of power from the administrative law's perspective showed that penal settlement did not become the first effort or primum remedium. ${ }^{9}$ The differences perspective from administrative and penal views, might not be controverted since each has different examination and laws, so it is no need to further debate. ${ }^{10}$ It is important to harmonize and synchronize the regulations about the state financial loss, and the administrative sanctions are given to the government officials refer to the case. ${ }^{11}$ It shows that the new regulations should follow with appropriate regulations, to get law enforcement and legal certainty.

Besides Article No. 20 and 21, there is Article No. 53 of Law No 30 of 2014 concerning Government Administration, also expand the competence of the Court. The article No. 53 regulates when the government do not issue the decree and/ or an act within 10 (ten) working days. The application considers being granted legally. This is called positive fictitious. The applicant can make an application to the Court to issue the decree of application which should be grant, and the Court should proceed and finalized within 21 (twentyone) working days. The government should make a decree based on judge verdict within 5 (five) working days.

There are no regulations of how the Court should proceed and implement the Article 53 Law No. 30 of 2014 concerning Government Administration,

\footnotetext{
${ }^{9}$ Disiplin F Manao, "Penyelesaian Penyalahgunaan Wewenang Oleh Aparatur Pemerintah Dari Segi Hukum Administrasi Dihubungkan Dengan Tindak Pidana Korupsi," Wawasan Yuridika 2, No. 1 (2018): 1-22, https://doi.org/10.25072/jwy.v2i1.158.

${ }^{10}$ Yulius, "Perkembangan Pemikiran Dan Penyalahgunaan Wewenang Di Indonesia (Tinjauan Singkat Dari Perspektif Hukum Administrasi Negara Pasca Berlakunya UU No. 30 Tahun 2014)," Jurnal Hukum Dan Peradilan 4, No. 3 (2015): 377, https://doi.org/10.25216/jhp.4.3.2015.361-384.

${ }^{11}$ Enrico Simanjuntak, "Penyalahgunaan Wewenang (Sebuah Refleksi Atas Putusan MK No.25/PUU-XIV/2016) Criminal And Administrative Law: An Urgent Necessity of Harmonization in Eradicating Maladministration Associated with Abuse of Power (A Reflection of Constitutional Co," Jurnal Hukum Peratun 1, No. 1 (2018): 33-56.
} 
and this is become a legal problem, besides Article 20 and 21. The Supreme Court had been issued the Regulation of Supreme Court No. 5 of 2015 concerning Guidance to Obtain The Verdict of Grant Application of Decree and/or an act by the Government. Still, this regulation could not give clear guidance to the Judges when there is an application based on Article 53 Law No 30 of 2014 concerning Government Administration.

Article 87 Law No. 30 of 2014 concerning Government Administration, expand the meaning of decree as mention in Law No. 5 of 1986 concerning Administrative Court and its amendments, this is not related with the competence, but it also needs clear explanations. In the article No. 87 Law no. 30 of 2014 concerning Government Administration, should be understood more broadly than as stated in the article No. 1 Law No. 5 of 1986 concerning Administrative Court. This broadly meaning of administrative decree should have a clear explanation because it makes it difficult to implement and understand.

Based on Article 28 D para 1 of the 1945 Constitution of Indonesia, there is still space for people to get access to justice, it is necessary to give more space to the Plaintiff. The changes of regulations should not be detrimental the people, as this is the constitutional rights. ${ }^{12}$ It is the state obligations to give the people their rights of access to justice, to protect and guarantee their rights.

Before Law No. 30 of 2014 concerning Governance Administration was legalized, Mafthuh Effendi said, it is necessary to extend the competence of the Administrative Court in two ways, i.e. first by using the general method, and second by using the benchmark of subject and object. ${ }^{13}$ He explained that the general method is used to determine the government's administrative decision, and the benchmark can be distinguished by the subject and object of a lawsuit. It can be understood that at the first time the Law No. 5 of 1986 concerning Administrative Court had been legalized, this narrow competence might be appropriate since there were different politic conditions.

When the competence is narrow, then it makes it difficult for the Court to solve other administrative disputes and it is far to reach the administrative justice, rather than legal certainty. On the contrary, when the competence become broader, so the Court can solve other administrative disputes and administrative justice, but legal certainty becomes further, this is the same opinion of Mafthuh Effendi, Yos Johan Utama also research result of Adriann

12 Tri Cahya Indra Permana, "Peradilan Tata Usaha Negara Pasca Undang-Undang Administrasi Pemerintahan Ditinjau Dari Segi Access To Justice (The Administrative Court After Government Administration Acts In Terms of Access To Justice)," Jurnal Hukum Dan Peradilan 4, No. 3 (2015): 419-42, https://doi.org/10.25216/jhp.4.3.2015.419-442.

13 Maftuh Effendi, "Peradilan Tata Usaha Negara Indonesia Suatu Pemikiran Ke Arah Perluasan Kompetensi Pasca Amandemen Kedua Undang-Undang Peradilan Tata Usaha Negara," Jurnal Hukum dan Peradilan 3, No. 1 (2014): 25-35, https://doi.org/10.25216/jhp.3.1.2014.25-36 
Bedner, recommend for the Court to have broader competence, include all the government's act based on public law. ${ }^{14}$ This opinion is appropriate with the dynamic changes in regulations and society.

The above opinions refer to Gustav Radburch's theory; the aims of law are legal certainty, justice, the expediency of law. Radburch's said when it comes together with the 3 (three) aims of the law. Then justice should be prior, expediency and legal certainty. ${ }^{15}$ Relates to broader competence of the Court, it can understand that it will give a chance to get justice in administrative disputes.

Cases that undergo through Court are administrative disputes and based on the competence. It means that the competence of the Court is to investigate, decide and settle administrative disputes. But when the competence becomes broader than before, the cases also vary. The object of administrative disputes may classify into some subjects, i.e. land-own certificate, immigration, licensing, environmental, auction, trademark, government employment disputes. Following the development of law, politics, there are some interest objects: the public information disclosure disputes, election administrative dispute settlement, dispute of administrative election violation, which based on different regulations. The system of dispute settlement for the election of administrative, dispute of administrative election violation are different from the Law No. 5 of 1986 concerning Administrative Court and its amendments and based on different Supreme Court Regulations.

Dispute arise based on Law No. 14 of 2008 concerning Public Information Disclosure also has to settle in the Court. The case of public information disputes has to finalized in the administrative stage before putting as a lawsuit to the Court. To settle the dispute of public information disputes follows Law No. 5 of 1986 concerning Administrative Court and its amendments.

The Law No. 7 of 2017 concerning General Election gives competence to the Court, Supreme Court to settle the arise disputes, but Law No. 10 of 2016 of Second Amendment of Law No. 1 of 2015 gives different competence to High Court of Administrative Court and Supreme Court. Based on the different acts, the cases also differ, and they should settle refer to a different system of the Court. This broader competence gives a different views of the meaning of administrative disputes as already knows by the public.

The decree of government in many sectors is vulnerable to become an object of disputes. The disputes in environment permission are also interesting, because it contributes in the reuse of environment, protection of the environment, fulfil the rights to have a good and clean environment, which are important for the next generations, renewable resources. The Court has an

\footnotetext{
14 Maftuh Effendi, Dinamika Yurisdiksi Peradilan Administrasi, ed. Tisnanta (Bandar Lampung: Pusaka Media, 2018).

15 Irvan Mawardi, Paradigma Baru PTUN Respon Peradilan Administrasi Terhadap Demokratisasi (Yogyakarta: Thafa Media, 2016).
} 
important role in controlling the government by investigating the disputes of environment permission. Another important role is law enforcement of administrative sanctions as putting in Law No. 32 of 2009 concerning The Protection and Management of Environment, besides penal sanction and fine against the law. To support the goals, the judge should have a certificate as an environment judge. This means that environment disputes have a different character and should have the same perception of the environment.

In German Law of Administrative Court Procedure, what kind of administrative act that can be brought to the Administrative Court, depends on the Plaintiff wishes to achieve and the subject of the disputes; and there is no actio popularis, it means to make a lawsuit, should be the legal standing in person. ${ }^{16}$ In the regulations, the competence of the Court also expands and vary. Furthermore, it gives access to justice for everyone proportionally.

Based on the statute and history approach, there is a shifting paradigm of the function and competence of the Court. The concept of The Court become broader than previously, follows the shifting paradigm of administrative law and dynamic changes of society. The development and changes in politics are contributing to the shifting paradigm of the Court.

The changes of statutes, the concept of the Court shows that it is relevant with the legal certainty of protection and guarantee of civil rights and government's law to keep the balance of rights and obligations of each. The justice is before a citizen of the civil rights to get administrative justice, follows the expediency of law.

\section{The administrative justice}

The administrative law in Indonesia had significant development, as we have seen in the last decade. This can not disregard the changes of politic, economy and law which had been happened for some years. The Law No. 30 of 2014 concerning Governance Administration has a new paradigm in administrative law, and it has to be synchronized and harmonized to the Court because it is very urgent for the development of law especially in administrative law and should be a complete and comprehensive approach. Some regulations have been issued by the Supreme Court to implement to the Court, and then hopefully it will not obstruct the access to justice.

Indonesia system of law follows the civil law system when case law is not a binding precedent, unlike in the common law system. While in the common law system, case law as the binding force of precedent based on stare decis doctrine, and judge made-law, so the case law as the primary source of law, the same as regulations or acts in the civil law system. This divergence

\footnotetext{
${ }^{16}$ Urs Kramer, Tim Hinrichsen, and Universität Passau, "German Law of Administrative Court Procedure: An Overview," Journal of Siberian Federal University Humanities and Social Sciences 10, No. 8 (2015): 2050-61, https://doi.org/10.17516/1997-1370-2015-8-10-20502061.Research.
} 
becomes important while the law is highly needed; on the other hand, we are trapped in the dichotomy of the binding force of precedent of case law.

The development of case law in administrative law is less since there are different views of the precedent and case law, the regulation from Supreme Court gives stressing the only procedural system. Sebastian Pompe stated that case law is court verdict, precedent is the binding force of verdict to the next judge. Charles J. Reid quoted from Blackstone that the core of precedent is court verdict as the authoritative principle of evidence. Enrico Simanjuntak stated, in the future, every case law should be as relevant as to the legal issues. Court has to participate in developing the law, and the stare decisis or binding precedent should be implemented in the judiciary system in Indonesia. ${ }^{17}$ The development of administrative disputes are varied, and the court has to give a verdict, it is important to give more attention to develop case law of administrative law to build and develop the law.

The shifting views of case law in Indonesia is urgent and important and to develop case law in administrative law as a binding force of precedent. As stated by Teguh Satya Bhakti, the Supreme Court has authority and responsibility to collect the case law, to preserve the unity of judiciary, there should be clear mechanism if the judge verdict will become case law. The mechanism is as follows: judge verdict has binding legal force, there is no regulation or the rule is not clear, has truth or justice value, has been followed many times by other judges, passed the examination process by the evaluation team of Supreme Court, and recommended as case law binding force of precedent. ${ }^{18}$ The case law in administrative law cannot develop properly unless The Supreme Court makes new regulations considering the existing conditions.

Judge is an important figure to make a verdict and settle the disputes, deliver justice, in line with the dynamic of society and evoke a new norm of law which might be useful. The judge has to know, follow the dynamic changes of society, and as a part of the judiciary system, they do not have the authority to make regulations.

Development of judicial activism is important and had been used for some years in the Court. ${ }^{19}$ Judicial activism needs to balance the disputes between parties to make justice as a law that lives dynamically in society. As Satjipto Rahardjo quoted Paul Scholten that justice is in the law, but it has to be found. Administrative justice can be implemented while judicial activism is used in

17 Enrico Simanjuntak, "Undang-Undang Administrasi Pemerintahan Public Litigation Advocacy After Enactment of Government Administration Law," Jurnal Ius Kajian Hukum Dan Keadilan, No. 30 (2018): 14-33.

${ }_{18}$ Teguh Satya Bhakti, Pembangunan Hukum Administrasi Negara Melalui Pemberdayaan Yurisprudensi Peradilan Tata Usaha Negara (Semarang: Universitas Diponegoro, 2017).

${ }^{19}$ Indriati Amarini, "Implementation of Judicial Activism in Judge's Decision," Jurnal Hukum Dan Peradilan 8, No. 1 (2019): 21-38, https://doi.org/10.25216/JHP.8.1.2019.21-38. 
judge verdict, in consideration and Based on the interview with Mr Himawan and $\mathrm{Mr}$ Gayuh Rahantyo, both are judges in Denpasar Administrative Court on 30-31 July 2019, informed that procedural is the important part, besides expediency and justice. Since this is an administrative dispute, the procedural examination is important. But while it meets with justice, the procedural is no longer prioritize, and justice as before settling the dispute.

Chief of Administrative Court of Surabaya, stated that the administrative justice could be fulfilled after defendant implements their duties based on judge verdict. The rights to put a lawsuit is a way to start a process to get administrative justice. Administrative justice as defined by Michael Adler, justice inherent to administrative decision-making, Mashaw has another opinion that administrative justice as qualities of the decision-making process that explain the acceptability and refer to internal decision-making, and others authors said that administrative justice is fair treatment of the individual by decision-making and able to redress of fairness. ${ }^{20}$

The Court function is to give protection of human rights, also has the corrective function of the judge to examine the government's decree sometimes can not fulfil justice of Plaintiff. Anshori said, as quoted by Riawan Tjandra, that justice as synchronizing legal certainty and proportional principle, and the essence of law enforcement. On the other side, Wiener introduced the theory of cybernetic law, that law as a center to control communication between individual. ${ }^{21}$ Referring to administrative justice, to get the essence of law enforcement, there should be control from government's officer or body in the process of decision-making. It should comply with all the regulations, norms, principle of good governance and communicate with society if necessary. As state law, justice can be seen in the judge verdict, regulations with different scope for purposes. Aristoteles said there is distributive and commutative justice, which relates to administrative justice as it is in a frame of state of law and reasonable principle. Based on the rights of citizens in the relations with the state, it is called distributive justice. The rights between citizens to distribute on what they should have based on equal positions is commutative justice.

The administrative justice refers to distributive justice as it is related to the civil rights of citizens. The broader competence of the court must relate to civil rights to fulfil their rights. Others said that justice is inherent with the aims of the law, as stated by Rudolph Heimanson and quoted by Bahder Johan

\footnotetext{
${ }^{20}$ Sergio López-Ayllón, Adriana García, and Ana Elena Fierro, “A Comparative-Empirical Analysis of Administrative Courts in Mexico," Mexican Law Review 7, No. 2 (2015): 3-35, https://doi.org/10.1016/S1870-0578(16)30001-4.

${ }^{21}$ Willy Riawan Tjandra, "Dinamika Keadilan Dan Kepastian Hukum Dalam Peradilan Tata Usaha Negara," Mimbar Hukum Special Ed, no. Edisi khusus (2011): 75-88, http://download.portalgaruda.org/article.php?article=281481\&val=7175\&title=Dinamika Keadilan dan Kepastian Hukum dalam Peradilan Tata Usaha Negara.
} 
Nasution, define law as rectify the mistakes, finding balancing but raise the conflicting of interest. Tourtoulon said "lex injusta non est lex" means law in unjustice is not law. ${ }^{22}$ Administrative justice is classified as distributive justice since it relates to the government to fulfil the citizen's rights. Government has to give fair, proper treatment to an individual in the process of issuing the decision based on the published information. Administrative requirements should be detail, easy and clear to understand, no bias, for an application unless there will be a disruption to get the administrative justice from the beginning.

According to the Court, administrative justice is rights to claim for decree since there is an infringement of decision-making, and procedural. Substance and authority are the issues of an investigation by the judge. It still continues until the implementation of the judge verdict as the law enforcement of administrative law. The defendant must obey the judge verdict and implement it properly and has to give compensation if they can not fulfil their obligations. The Defendant needs to put this obedience as before law certainty and enforcement.

\section{Conclusion}

The shifting paradigm of function and competence of the Court is broader than before. It gives more opportunity for everyone to get access to justice. The type of disputes gives benefit for everyone they will experience administrative justice more systematic than before. Administrative justice can be implemented in some ways. First, it is the rights of an individual. Therefore, the government has to provide detail, clear information for any individual before issuing a decree based on the application, rights to claims and revision for any mistakes. Second, the defendant has an obligation to obey and implement the judge verdict. This obligation as an implementation of administrative justice and legal certainty for Plaintiff and obedience by the Defendant to the judge verdict. Third, administrative justice should be supported by the regulations by obeying the judge verdict. This is part of improving the quality of governance.

\section{Bibliography}

Amarini, Indriati. "Implementation of Judicial Activism in Judge's Decision." Jurnal Hukum dan Peradilan 8, No. 1 (2019): 21-38. https://doi.org/10.25216/JHP.8.1.2019.21-38.

\footnotetext{
${ }^{22}$ Bahder Johan Nasution, "Kajian Filosofis Tentang Konsep Keadilan Dari Pemikiran Klasik Sampai Pemikiran Modern," Yustisia 3, No. 2 (2014), https://doi.org/10.20961/yustisia.v3i2.11106.
} 
Bhakti, Teguh Satya. Pembangunan Hukum Administrasi Negara Melalui Pemberdayaan Yurisprudensi Peradilan Tata Usaha Negara. Semarang: Universitas Diponegoro, 2017.

Bilkiewicz, Tatiana, J Bytiak, S Bondar, and A Borko. "Administrative Courts in Ukraine: Formation and Functioning in the Modern Conditions." Annuals of The Administration and Law 17, No. 17 (2017): 115-27.

Boughey, J Anina B. "Administrative Law: The next Frontier for Comparative Law J.” International and Law Quarterly 62, No. January (2013): 5595, https://doi.org/10.1017/S0020589312000553.

Effendi, Maftuh. "Peradilan Tata Usaha Negara Indonesia Suatu Pemikiran Ke Arah Perluasan Kompetensi Pasca Amandemen Kedua UndangUndang Peradilan Tata Usaha Negara." Jurnal Hukum dan Peradilan 3, No. 1 (2014): 25-35, https://doi.org/10.25216/jhp.3.1.2014.25-36.

Effendi, Maftuh. Dinamika Yurisdiksi Peradilan Administrasi. Edited by Dr.HS. Tisnanta. Bandar Lampung: Pusaka Media, 2018.

Enrico Simanjuntak. "Peradilan Tata Usaha Negara Dan Perlindungan Hak Asasi Manusia." In Perdebatan Hukum Administrasi Sebuah Kompilasi Artikel Hukum Administrasi, edited by Paskalina Oktavianawati, 3-29. Bekasi: Gramata Publishing, 2018. Obilade,A. The Nigerian Legal System. London: Sweet \& Maxwel, 1981.

Kramer, Urs, Tim Hinrichsen, and Universität Passau. "German Law of Administrative Court Procedure: An Overview." Journal of Siberian Federal University Humanities and Social Sciences 10, No. 8 (2015): 2050-61. https://doi.org/10.17516/1997-1370-2015-8-10-20502061.Research.

Law No. 10 of 2016 concerning Second Amendment of Law No 1 of 2015 (State Gazette No. 130 of 2016, Additional State Gazette No. 5898)

Law No. 14 of 2008 concerning Public Information Disclosure (State Gazette No. 61 of 2008, Additional State Gazette No. 4846)

Law No. 30 of 2014 concerning Administrative Governance (State Gazette No. 292 of 2014, Additional State Gazette No. 5601)

Law No. 32 of 2009 concerning The Protection and Management of Environment (State Gazette No. 140 Year 2009, Additional State Gazette No. 5059)

Law No. 5 of 1986 concerning Administrative Court (State Gazette No. 77 of 1986, Additional State Gazette No. 3344)

Law No. 51 of 2009 concerning Second Amendment of Act No. 5 of 1986 concerning Administrative Court ( State Gazette No. 160 of 2009, Additional State Gazette No. 5079)

Law No. 7 of 2017 concerning General Election (State Gazette No. 182 of 2017, Additional State Gazette No. 6109) 
Law No. 9 of 2004 concerning Amendment of Law No 5 of 1986 concerning Administrative Court ( State Gazette No. 35 of 2004, Additional State Gazette No. 4380)

López-Ayllón, Sergio, Adriana García, and Ana Elena Fierro. "A Comparative-Empirical Analysis of Administrative Courts in Mexico." Mexican Law Review 7, No. 2 (2015): 3-35, https://doi.org/10.1016/S1870-0578(16)30001-4.

Manao, Disiplin F. "Penyelesaian Penyalahgunaan Wewenang Oleh Aparatur Pemerintah Dari Segi Hukum Administrasi Dihubungkan Dengan Tindak Pidana Korupsi.” Wawasan Yuridika 2, No. 1 (2018): 1-22, https://doi.org/10.25072/jwy.v2i1.158.

Mawardi, Irvan. Paradigma Baru PTUN Respon Peradilan Administrasi Terhadap Demokratisasi. Yogyakarta: Thafa Media, 2016.

Nasution, Bahder Johan. "Kajian Filosofis Tentang Konsep Keadilan Dari Pemikiran Klasik Sampai Pemikiran Modern.” Yustisia 3, No. 2 (2014), https://doi.org/10.20961/yustisia.v3i2.11106.

Oughey, J Anina B. "Administrative Law: The next Frontier for Comparative

Law J." International and Law Quarterly 62, no. January (2013): 5595, https://doi.org/10.1017/S0020589312000553.

Pair, Lara M. "Judicial Activism in the ICJ Charter Interpretation." Journal of International and Comparative Law 8 (2001): 181-221.

Permana, Tri Cahya Indra "Peradilan Tata Usaha Negara Pasca UndangUndang Administrasi Pemerintahan Ditinjau Dari Segi Access To Justice ( The Administrative Court After Government Administration Acts In Terms of Access To Justice)." Jurnal Hukum dan Peradilan 4, No. 3 (2015): 419-42, https://doi.org/10.25216/jhp.4.3.2015.419-442.

Riawan Tjandra, Willy. "Dinamika Keadilan Dan Kepastian Hukum Dalam Peradilan Tata Usaha Negara." Mimbar Hukum, No. Special Edition (2011): 75-88.

Sahlan, Mohammad. "Kewenangan Peradilan Tipikor Pasca Berlakunya Undang-Undang No. 30 Tahun 2014 Tentang Administrasi Pemerintahan." Arena Hukum 9, No. 2 (2016): 166-89, https://doi.org/10.21776/ub.arenahukum.2016.00902.2.

Simanjuntak, Enrico. "Penyalahgunaan Wewenang (Sebuah Refleksi Atas Putusan MK NO.25/PUU-XIV/2016) Criminal and Administrative Law: An Urgent Necessity of Harmonization in Eradicating Maladministration Associated with Abuse of Power (A Reflection of Constitutional Co." Jurnal Hukum Peratun 1, No. 1 (2018): 33-56.

Simanjuntak, Enrico. "Undang-Undang Administrasi Pemerintahan Public Litigation Advocacy After Enactment of Government Administration Law.” Jurnal Ius Kajian Hukum an Keadilan, No. 30 (2018): 14-33. 
Subechi, Imam. "Mewujudkan Negara Hukum Indonesia." Jurnal Hukum dan Peradilan $1, \quad$ No. 3 (2012): $339-58$. https://doi.org/10.25216/jhp.1.3.2012.339-358.

Wairocana, I Gusti Ngurah, I Ketut Sudiarta, I Wayan Bela, Siki Layang, Kadek Agus Sudiarawan, and I Gede Pasek Pramana. "The Expansion of Administrative Decision Meaning Based on Government Administration Law: A Dispute Submission Process Approach." (2019): 13-33. https://doi.org/10.24843/JMHU.2019.v08.i01.p02.

Yulius. "Perkembangan Pemikiran Dan Penyalahgunaan Wewenang Di Indonesia (Tinjauan Singkat Dari Perspektif Hukum Administrasi Negara Pasca Berlakunya UU No 30 Tahun 2014 )." Jurnal Hukum dan Peradilan 4 , No. 3 (2015): 377, https://doi.org/10.25216/jhp.4.3.2015.361-384.

\section{Grants}

Internal funds Universitas Diponegoro in 2019. 